University of Nebraska - Lincoln

DigitalCommons@University of Nebraska - Lincoln

Biological Systems Engineering: Papers and

Publications

Biological Systems Engineering

$1-2000$

\title{
Water vapor transport parameters of a cast wheat gluten film
}

Soumya Roy

General Mills, Inc., Minneapolis, MN

Aristippos Gennadios

Banner Pharmacaps Inc., aris.gennadios@catalent.com

Curtis Weller

University of Nebraska-Lincoln, cweller1@unl.edu

Robert F. Testin

Clemson University

Follow this and additional works at: https://digitalcommons.unl.edu/biosysengfacpub

Part of the Biological Engineering Commons

Roy, Soumya; Gennadios, Aristippos; Weller, Curtis; and Testin, Robert F., "Water vapor transport parameters of a cast wheat gluten film" (2000). Biological Systems Engineering: Papers and Publications. 199.

https://digitalcommons.unl.edu/biosysengfacpub/199

This Article is brought to you for free and open access by the Biological Systems Engineering at DigitalCommons@University of Nebraska - Lincoln. It has been accepted for inclusion in Biological Systems Engineering: Papers and Publications by an authorized administrator of DigitalCommons@University of Nebraska Lincoln. 
Published in Industrial Crops and Products 11:1 (January 2000), pp. 43-50; doi: 10.1016/S0926-6690(99)00032-1

Copyright () 2000 Elsevier Science B.V. Used by permission.

Submitted April 8, 1999; accepted July 19, 1999; published online December 9, 1999.

Journal Series No. 11720, Agricultural Research Division, Institute of Agriculture and Natural Resources, University of Nebraska-Lincoln; Technical Contribution No. 4258 of the South Carolina Agricultural Experiment Station, USA.

\title{
Water vapor transport parameters of a cast wheat gluten film
}

\author{
Soumya Roy, ${ }^{1}$ Aristippos Gennadios, ${ }^{2}$ Curtis L. Weller, ${ }^{3}$ and Robert F. Testin ${ }^{4}$ \\ 1. General Mills, Inc., Minneapolis, MN 55427, USA \\ 2. Materials Science Group, Research and Development, Banner Pharmacaps Inc., \\ 4125 Premier Drive, High Point, NC 27265-8144, USA \\ 3. Departments of Biological Systems Engineering and Food Science and Technology, \\ University of Nebraska-Lincoln, Lincoln, NE 68583-0726, USA \\ 4. Faculties of Packaging Science and Agricultural and Biological Engineering, \\ Clemson University, Clemson, SC 29634-0370, USA \\ Corresponding author - A. Gennadios, tel 336 812-8700, fax 336 812-9091, email agennadios@banpharm.com
}

\begin{abstract}
Understanding the mode of transport of water vapor through the film is important for improving the moisture barrier properties of wheat gluten (WG) films. Effective permeability $\left(P_{\text {eff }}\right)$, solubility $\left(S_{\text {eff }}\right)$, and diffusion $\left(D_{\text {eff }}\right)$ coefficients of a hydrophilic cast WG film were determined at $25^{\circ} \mathrm{C}$ within the relative humidity $(\mathrm{RH})$ range of $0-84 \%$ (with a $9-13 \% \mathrm{RH}$ gradient between upstream and downstream water vapor flux). $P_{\text {eff }} S_{\text {eff }}$ and $D_{\text {eff }}$ increased substantially as the RH gradient moved upwards in the $\mathrm{RH}$ spectrum. $P_{\text {eff }}$ increased by four orders of magnitude from the lowest $\mathrm{RH}$ condition of $0-11 \%\left(3.8 \times 10^{-11} \mathrm{~g} \mathrm{~m} / \mathrm{m}^{2} \mathrm{~s} \cdot \mathrm{Pa}\right)$ to the highest $\mathrm{RH}$ condition of $75-84 \%\left(4.1 \times 10^{-7}\right.$ $\mathrm{g} \mathrm{m} / \mathrm{m}^{2} \mathrm{~s} \cdot \mathrm{Pa}$ ). A moisture sorption isotherm of the film at $25^{\circ} \mathrm{C}$ was constructed. Both the Guggenheim-Anderson-DeBoer (GAB) and the Kuhn moisture sorption isotherm models showed a good fit to the experimental adsorption data. Testing of WG films at the expected conditions of actual use is necessary to quantify the water vapor permeation through the films.
\end{abstract}

Keywords: diffusion, permeability, protein films, sorption isotherm, wheat gluten

\section{Introduction}

Concerns over solid packaging waste have increased interest in biopolymer films and coatings. Such films, comprised of protein, polysaccharide, and/or lipid materials, are renewable, possibly edible, and can lead to innovative packaging applications. Due to its unique cohesive and elastic properties, wheat gluten (WG) has been studied as a film former (Gennadios et al., 1994a). WG 
films are effective oxygen barriers, but poor water vapor barriers (Gennadios et al., 1994a). Limited improvements in water vapor barrier properties of WG films have been achieved (Gennadios et al., 1993; Gontard et al., 1994; Ali et al., 1997). The poor resistance of WG films to water vapor is due to the hydrophilic nature of the protein and to the substantial amount of hydrophilic plasticizer added to impart adequate film flexibility. Understanding the mode of transport of water vapor through the film is important for improving the moisture barrier properties of WG films.

Water vapor transport through polymer films proceeds through: (i) absorption of water vapor on to the polymer surface; (ii) solution of water vapor into the polymer matrix; (iii) diffusion of water vapor through the polymer; and (iv) desorption of water vapor from the other surface of the polymer (Debeaufort et al., 1994). Water vapor permeability $(P)$ is defined as (Rogers, 1985):

$$
P=D \cdot S
$$

where $P$ is permeability coefficient $\left(\mathrm{g} \cdot \mathrm{m} / \mathrm{m}^{2} \cdot \mathrm{s} \cdot \mathrm{Pa}\right)$; $D$ is diffusion coefficient $\left(\mathrm{m}^{2} /\right.$ day); and $S$ is solubility or sorption coefficient $\left(\mathrm{g} / \mathrm{m}^{3} \cdot \mathrm{Pa}\right)$.

Ideally, when no interaction occurs between a polymer film and the permeating water vapor, $P$ is independent of the apparent equilibrium water vapor pressure corresponding to the water activity $\left(a_{\mathrm{w}}\right)$ of the film (Ashley, 1985). Hydrophobic films, such as polyethylene, have water vapor permeabilities independent of the water vapor pressure (Myers et al., 1962). However, permeation of water vapor through hydrophilic films deviates substantially from the ideal behavior. Protein-based films, similar to other hydrophilic films, exhibit water vapor pressure-dependent permeability (Ashley, 1985). Water vapor permeability measurements of WG films have been reported (Aydt et al., 1991; Gontard et al., 1992; Gennadios et al., 1994b; Herald et al., 1995; Park and Chinnan, 1995). However, such water vapor permeability measurements were limited to one or two relative humidity $(\mathrm{RH})$ gradient conditions and these values cannot be used to predict transport properties of these films at different RH gradient conditions. Water vapor transmission rates (WVTR) of WG films determined by Gontard et al. (1993) in the range of $10-90 \% \mathrm{RH}$ at a $\mathrm{RH}$ gradient of $10 \pm$
$1 \%$ across films, showed the dependence of $\mathrm{P}$ on RH. Schwartzberg (1986) observed that the failure to account for air resistance across the upstream and downstream surfaces of hydrophilic films leads to a substantial underestimation of the film diffusion coefficient. Gontard et al. (1993) did not separate upstream and downstream air resistances from that of the WG film itself and did not determine the film diffusion coefficients. Our study was aimed at determining the effect of moisture concentration on water vapor transport parameters (permeability, solubility, and diffusion coefficients) of a cast WG film.

\section{Materials and methods}

\subsection{Reagents}

Films were prepared using vital WG (WheatPro-80®, Ogilvie Mills, Quebec, Canada) with an approximate protein content of $80 \%$ (dry basis); ethyl alcohol, 95\% (v/v) (J.T. Baker, Phillipsburg, NJ); ammonium hydroxide, $5 \mathrm{~N}$ (Aldrich, Milwaukee, WI); and glycerol (Fisher Scientific, Fair Lawn, NJ). Salts used to create different RH conditions (Table 1) were anhydrous calcium sulfate (W.A. Hammond Drierite, Xenia, $\mathrm{OH}$ ), lithium chloride, potassium acetate, magnesium chloride, potassium carbonate, magnesium nitrate, sodium bromide, strontium chloride, sodium chloride, and potassium chloride (reagent grade, Mallinkrodt, Paris, KY).

Table 1. Relative humidity $(\mathrm{RH})$ gradients created at $25^{\circ} \mathrm{C}$ by anhydrous calcium sulfate and various saturated salt solutions (Wolf et al., 1984) for the determination of water vapor permeability

\begin{tabular}{lll}
\hline $\begin{array}{l}\text { Salt inside } \\
\text { cups }\end{array}$ & $\begin{array}{l}\text { Salt outside } \\
\text { cups }\end{array}$ & $\begin{array}{l}\mathrm{RH} \text { gradient } \\
(\%)\end{array}$ \\
\hline $\mathrm{CaSO}_{4}$, anhydrous & $\mathrm{LiCl}$ & $0.00-11.15$ \\
$\mathrm{LiCl}$ & $\mathrm{CH}_{3} \mathrm{COOK}$ & $11.15-22.60$ \\
$\mathrm{CH}_{3} \mathrm{COOK}$ & $\mathrm{MgCl}_{2}$ & $22.60-32.73$ \\
$\mathrm{MgCl}_{2}$ & $\mathrm{~K}_{2} \mathrm{CO}_{3}$ & $32.73-43.80$ \\
$\mathrm{~K}_{2} \mathrm{CO}_{3}$ & $\mathrm{Mg}\left(\mathrm{NO}_{3}\right)_{2}$ & $43.80-52.86$ \\
$\mathrm{NaBr}$ & $\mathrm{SrCl}_{2}$ & $57.70-70.83$ \\
$\mathrm{NaCl}$ & $\mathrm{KCl}$ & $75.32-84.32$ \\
\hline
\end{tabular}




\subsection{Film preparation}

The film preparation method described by Gennadios et al. (1993) was followed. WG (15 g) was added to $95 \%$ ethanol $(72 \mathrm{ml})$ and glycerine $(6 \mathrm{~g})$. WG dispersion was facilitated by adding $14 \mathrm{ml}$ of $5 \mathrm{~N}$ ammonium hydroxide and $48 \mathrm{ml}$ of distilled water, while warming and stirring on a magnetic stirrer/hot plate. A notable decrease in viscosity marked WG dispersion. The suspensions were heated to $75^{\circ} \mathrm{C}$ and then cooled to $45^{\circ} \mathrm{C}$, strained through cheese cloth to remove any small lumps, and cast on level flat glass plates with a thin-layer chromatography spreader (Brinkman, New York, NY). Castings were kept at ambient temperature for $\approx 20 \mathrm{~h}$ before the films were peeled off the plates.

\subsection{Film thickness and density}

Thickness of dried films was measured to the nearest $2.54 \mu \mathrm{m}(0.1 \mathrm{mil})$ with a hand-held $\mathrm{mi}-$ crometer (B.C. Ames, Waltham, MA). Five measurements were taken on each specimen and their mean was used in calculations. Densities were determined by weighing the film specimens $(3 \times 3 \mathrm{~cm})$ after drying in a desiccator over anhydrous calcium sulfate $(0 \% \mathrm{RH})$ for $7-10$ days. Films were considered dry when constant weight was recorded between two consecutive days of weighing. Film specimens had a mean thickness of $83 \pm 2 \mu \mathrm{m}$. Density was determined by dividing film weight by film volume. A mean dry film density value of $0.925 \pm 0.038 \mathrm{~g} / \mathrm{m}^{3}$ was obtained.

\subsection{Determination of water vapor permeability}

Seven different $\mathrm{RH}$ gradients (Table 1 ) were used to study the water vapor permeation through films. Permeability was measured gravimetrically using a variation of the method described by Gennadios et al. (1994c). Test cups consisted of a cylindrical well $(2.1 \mathrm{~cm}$ in depth) bored in a polymethylmethacrylate cylinder and a lid (with an opening in the center) of the same material. Both the cup well and the lid openings were 4.6 $\mathrm{cm}$ in diameter. The cups were filled with a saturated salt solution to $0.6 \mathrm{~cm}$ below the brim of the well. Film specimens were placed on top of the wells and secured beneath the lids by four screws, symmetrically placed around the lid perimeter. To ensure airtight sealing, high vacuum silicone grease was applied around the edge of the wells and under the lids.

The cups were placed on a weighing balance inside a sorbostat. The sorbostat was maintained at a lower RH than that in the cups (Table 1 ). The downstream resistance of air (Schwartzberg, 1986) was minimized by operating a fan inside the chamber to provide an airflow of $259 \mathrm{~m} /$ min over the cups. McHugh et al. (1993) observed an increase in water vapor permeability of hydrophilic films with an increase in air flow rate up to $152 \mathrm{~m} / \mathrm{min}$, after which the increase was negligible. The rate of weight loss, which was constant at steady state, was used to calculate $P$. When Henry's law is obeyed, the loss rate or WVTR is (Rogers, 1985):

$$
\mathrm{WVTR}=D S\left(p_{W 1}-p_{W 2}\right) / l
$$

where WVTR is water vapor transmission rate $(\mathrm{g} /$ $\left.\mathrm{m}^{2} \mathrm{~s}\right) ; p_{\mathrm{W} 1}$ is partial pressure of water vapor at the underside of the film $(\mathrm{Pa}) ; p_{\mathrm{W} 2}$ is partial pressure of water vapor at the film surface outside the cup (Pa); and $l$ is film thickness $(\mu \mathrm{m})$.

Partial pressure of water vapor at the underside of the film $\left(p_{\mathrm{W} 1}\right)$ was calculated from (Gennadios et al., 1994c):

$$
\begin{aligned}
p_{\mathrm{W} 1}=p_{\mathrm{T}} & -\left(p_{\mathrm{T}}-p_{\mathrm{W} 0}\right) \\
\cdot & \exp \left[\left(R \cdot T \cdot \mathrm{WVTR} \cdot h_{\mathrm{i}}\right) /\left(p_{\mathrm{T}} \cdot D_{\text {air }}\right)\right]
\end{aligned}
$$

where $p_{\mathrm{T}}$ is total atmospheric pressure $(\mathrm{Pa}) ; p_{\mathrm{W} 0}$ is partial pressure of water vapor in air at the surface of distilled water or saturated salt solution in the cup $(\mathrm{Pa}) ; R$ is universal gas constant $(8,306,600$ $\left.\mathrm{Pa} \cdot \mathrm{cm}^{3} / \mathrm{gmol} \mathrm{K}\right)$; $\mathrm{T}$ is absolute temperature during testing $(\mathrm{K})$; $h_{\mathrm{i}}$ is the gap between the film underside and the surface of saturated salt solution in the cup (cm); and $D_{\text {air }}$ is the diffusion coefficient of water vapor in air $\left(\mathrm{cm}^{2} / \mathrm{s}\right)$, which is $0.26 \mathrm{~cm}^{2} / \mathrm{s}$ at $25^{\circ} \mathrm{C}$. 
Equations (1) and (2) were combined to obtain Equation (4):

$$
P=\mathrm{WVTR} \cdot l /\left(p_{\mathrm{w} 1}-p_{\mathrm{w} 2}\right)
$$

Due to the hydrophilic nature of films, both $D$ and $S$ vary with concentration and pressure gradient. Therefore, $P$ also depends on those variables. Thus, $P$ is replaced by $P_{\text {eff }}$ (effective water vapor permeability coefficient in $\mathrm{g} / \mathrm{m} \mathrm{s} \cdot \mathrm{Pa}$ ) in Equation (4), and Equation (1) becomes:

$$
P_{\text {eff }}=D_{\text {eff }} \cdot S_{\text {eff }}
$$

where $D_{\text {eff }}$ is effective diffusion coefficient $\left(\mathrm{m}^{2} /\right.$ day) and $S_{\text {eff }}$ is effective solubility coefficient (g/ $\left.\mathrm{m}^{3} \cdot \mathrm{Pa}\right)$.

\subsection{Determination of moisture adsorption isotherm}

Prior to the moisture adsorption experiments, film specimens $(3 \times 3 \mathrm{~cm})$ were brought to zero moisture content by equilibrating them over anhydrous calcium sulfate $(0 \% \mathrm{RH})$ in a desiccator. The samples were weighed daily and equilibrium was assumed to have been reached when the weight change of samples between two consecutive days was less than $0.001 \mathrm{~g}$ water/g of dry matter (Gennadios and Weller, 1994). Equilibrium was observed within 10 days. The desorbed samples were weighed into aluminum dishes and suspended inside glass sorbostats containing saturated salt solutions. Prior to introducing the samples, the targeted RHs of the sorbostats were verified using a thermohygrometer (model HI 8564, Hanna Instruments, Woonsocket, RI). Sorbostats containing saturated salt solutions of $\mathrm{LiCl}, \mathrm{CH}_{3} \mathrm{COOK}, \mathrm{MgCl}_{2}, \mathrm{~K}_{2} \mathrm{CO}_{3}$, $\mathrm{Mg}\left(\mathrm{NO}_{3}\right)_{2}, \mathrm{SrCl}_{2}, \mathrm{NaCl}$, or $\mathrm{KCl}$ had equilibrium $\mathrm{RH}$ values close to $11,23,33,44,53,71,75$, or $84 \%$, respectively (Wolf et al., 1984). The samples reached equilibrium within 9 days (as observed by a weight change of less than $0.001 \mathrm{~g}$ water $/ \mathrm{g}$ of dry matter in two consecutive daily weighings). The sorption study was replicated three times. Experimental water adsorption data were fitted with six different sorption isotherm models (Table 2). The parameters of the models were estimated with the nonlinear regression (NLIN) procedure in SAS (1993) software. Accuracy of fit was evaluated by the mean of the relative percent difference between the experimental and predicted values of the moisture content or mean relative deviation modulus $(G)$ defined as (Gencturk et al., 1986):

$$
G=(100 / n) \cdot \sum\left(\left|M_{\mathrm{a}}-M_{\mathrm{p}}\right| / M_{\mathrm{a}}\right)
$$

where $n$ is number of observations; $M_{\mathrm{a}}$ is experimentally determined moisture content $(\mathrm{g} / \mathrm{g}$ dry solids); and $M_{\mathrm{p}}$ is predicted moisture content $(\mathrm{g} / \mathrm{g}$ dry solids).

A $G$ value lower than 5 corresponds to extremely good fit, a $G$ value between 5 and 10 shows a reasonably good fit, and a $G$ value greater than 10 is considered a poor fit (Gencturk et al., 1986).

\subsection{Calculation of solubility and diffusion coefficients}

The fitted GAB equation was used to estimate the moisture content of each film specimen surface in the permeability study. The $S_{\text {eff }}$ value for each pressure gradient was obtained from:

$$
S_{\text {eff }}=\left[\left(M_{1}-M_{2}\right) /\left(p_{\mathrm{w} 1}-p_{\mathrm{w} 2}\right)\right] d
$$

where $M_{1}$ is moisture content of film at its underside surface (g/g solids); $M_{2}$ is moisture content of film at its surface outside the cup (g/g solids); and $d$ is dry film density $\left(\mathrm{g} / \mathrm{cm}^{3}\right)$.

Table 2. Moisture sorption isotherm models fitted to experimental adsorption isotherm data of a wheat gluten film ${ }^{\mathrm{a}}$

\begin{tabular}{lll}
\hline Name & Model & Reference \\
\hline Smith & $M=A-\left[B \ln \left(1-a_{\mathrm{w}}\right)\right]$ & Smith (1947) \\
Oswin & $M=A\left[a_{\mathrm{w}} /\left(1-a_{\mathrm{w}}\right)\right]^{B}$ & Oswin (1946) \\
Halsey & $M=A\left[-1 / \ln \left(T a_{\mathrm{w}}\right)\right]^{B}$ & $\begin{array}{c}\text { Boquet et al. } \\
(1978)\end{array}$ \\
Flory-Huggins & $M=A \exp \left(B a_{\mathrm{w}}\right)$ & Rogers (1985) \\
Kuhn & $M=\left[A\left(-1 / \ln \left(a_{\mathrm{w}}\right)\right)^{B}\right]+C$ & Kuhn (1964) \\
GAB & $M=\left(M_{0} k C a_{\mathrm{w}}\right) /\left[\left(1-k a_{\mathrm{w}}\right)\right.$ & Bizot (1984) \\
& $\left.\left(1-k a_{\mathrm{w}}+k C a_{\mathrm{w}}\right)\right]$ &
\end{tabular}

a. $M$, equilibrium moisture content (g water/g dry matter); $M_{0}$, monolayer moisture content ( $\mathrm{g}$ water/g dry matter; $a_{\mathrm{w}}$, water activity; $A, B, C, k$, constants. 
Table 3. Water vapor permeability coefficients $\left(P_{\text {eff }}\right)$, solubility coefficients $\left(S_{\text {eff }}\right)$ and diffusion coefficients $\left(D_{\text {eff }}\right)$ of wheat gluten films at different $\mathrm{RH}$ gradients

\begin{tabular}{lllll}
\hline RH gradient $(\%)$ & Film thickness $(\mu \mathrm{m})$ & $P_{\text {eff }}\left(\mathrm{g} \times \mathrm{m} / \mathrm{m}^{2} \times \mathrm{S} \times \mathrm{Pa}\right)$ & $S_{\text {eff }}\left(\mathrm{g} / \mathrm{m}^{3} \times \mathrm{Pa}\right)$ & $D_{\text {eff }}\left(\mathrm{m}^{2} /\right.$ day $)$ \\
\hline $0.00-11.15$ & 81 & $3.8 \pm 0.4 \times 10^{-11}$ & $37.91 \pm 0.01$ & $8.7 \pm 1.0 \times 10^{-8}$ \\
$11.15-22.60$ & 83 & $7.7 \pm 1.0 \times 10^{-11}$ & $44.68 \pm 0.02$ & $1.5 \pm 0.2 \times 10^{-7}$ \\
$22.60-32.73$ & 84 & $1.4 \pm 0.1 \times 10^{-10}$ & $54.81 \pm 0.02$ & $2.1 \pm 0.2 \times 10^{-7}$ \\
$32.73-43.80$ & 85 & $2.7 \pm 0.3 \times 10^{-10}$ & $70.34 \pm 0.15$ & $3.3 \pm 0.4 \times 10^{-7}$ \\
$43.80-52.86$ & 79 & $5.2 \pm 0.3 \times 10^{-10}$ & $92.58 \pm 0.18$ & $4.8 \pm 0.3 \times 10^{-7}$ \\
$57.70-70.83$ & 83 & $2.4 \pm 0.2 \times 10^{-9}$ & $147.98 \pm 0.98$ & $1.4 \pm 0.1 \times 10^{-6}$ \\
$75.32-84.32$ & 83 & $4.1 \pm 1.7 \times 10^{-7}$ & $308.78 \pm 0.31$ & $1.1 \pm 0.5 \times 10^{-4}$ \\
\hline
\end{tabular}

$D_{\text {eff }}$ for each pressure gradient studied was then calculated from:

$$
D_{\text {eff }}=P_{\text {eff }} / S_{\text {eff }}
$$

\section{Results and discussion}

\subsection{Effective water vapor permeability}

Experimentally determined $P_{\text {eff }}$ values for WG films at different $\mathrm{RH}$ gradients are shown in Table 3. Because water vapor permeability of hydrophilic protein films is affected by film thickness, an effort was made to reduce film thickness variability to a minimum $(79-85 \mu \mathrm{m})$. As expected with a hydrophilic film (Schwartzberg, 1986; McHugh and Krochta, 1994), $P_{\text {eff }}$ increased substantially with increasing RH. Specifically, $P_{\text {eff }}$ increased by four orders of magnitude from the lowest RH condition $(0-11 \%)$ to the highest $\mathrm{RH}$ condition (75$84 \%)$. Most likely, at the high RH, extensive swelling of the protein network caused by sorbed water enhanced water molecule diffusion, thus substantially reducing the water vapor barrier ability of films (Gontard et al., 1993). For the sake of comparison, Briston (1988) reported a $P$ value of 7.3$9.7 \times 10^{-13} \mathrm{~g} / \mathrm{m} \cdot \mathrm{s} \cdot \mathrm{Pa}$ for low density polyethylene film ( $25 \mu \mathrm{m}$ thick at $38^{\circ} \mathrm{C}$ and $90 \% \mathrm{RH}$ gradient). At a low RH condition, WG films exhibited 40-fold greater $P_{\text {eff }}$ values than low-density polyethylene. The $P_{\text {eff }}$ obtained in our study at $0-11 \% \mathrm{RH}$ was similar to that $\left(5.6 \times 10^{-11} \mathrm{~g} \mathrm{~m} / \mathrm{m}^{2} \cdot \mathrm{s} \cdot \mathrm{Pa}\right)$ reported by Gennadios et al. (1993) for WG films at comparable temperature and $\mathrm{RH}$ conditions. The slightly greater $P_{\text {eff }}$ reported by Gennadios et al. (1993) was probably due to the thicker films $(\approx 100 \mu \mathrm{m})$ used in that study. Generally, $P_{\text {eff }}$ of hydrophilic films increases with film thickness, as shown for protein films from sodium caseinate (McHugh et al., 1993) and soy protein isolate (Ghorpade et al., 1995).

\subsection{Moisture adsorption isotherm}

Moisture adsorption isotherm data of WG films at $25^{\circ} \mathrm{C}$ within the $11-84 \% \mathrm{RH}$ range are presented in Table 4. Estimated parameters and goodness of fit for the six fitted moisture sorption models are shown in Table 5. Both three-parameter models (Kuhn and GAB equations) showed better fits ( $G$ values of 3.54 and 7.24, respectively) than the twoparameter models. The GAB moisture sorption model is used widely for foods. It is an extension of the two-parameter BET (Brunauer-EmmettTeller) model, taking into account the modified

Table 4. Experimental and predicted (by the Kuhn and $G A B$ moisture sorption models) equilibrium moisture contents (g water/g dry matter) for adsorption isotherm of wheat gluten films at $25^{\circ} \mathrm{C}$

\begin{tabular}{llll}
\hline$a_{\mathrm{w}}$ & Experimental & Kuhn model & GAB model \\
\hline 0.11 & $0.0100 \pm 0.0015$ & 0.0082 & 0.0145 \\
0.23 & $0.0292 \pm 0.0027$ & 0.0309 & 0.0322 \\
0.33 & $0.0515 \pm 0.0024$ & 0.0523 & 0.0514 \\
0.44 & $0.0800 \pm 0.0030$ & 0.0803 & 0.0783 \\
0.53 & $0.1114 \pm 0.0024$ & 0.1096 & 0.1076 \\
0.71 & $0.2073 \pm 0.0071$ & 0.2064 & 0.2071 \\
0.75 & $0.2482 \pm 0.0204$ & 0.2476 & 0.2494 \\
0.84 & $0.3783 \pm 0.0213$ & 0.3865 & 0.3860 \\
\hline
\end{tabular}


Table 5. Parameter $(A, B$, and $C)$ estimates of various moisture sorption isotherm models and their goodness of fit (mean relative deviation modulus $G$ ) to moisture adsorption isotherm data of wheat gluten films at $25^{\circ} \mathrm{C}^{\mathrm{a}}$

\begin{tabular}{lrrll}
\hline Model & \multicolumn{1}{l}{ G } & \multicolumn{1}{l}{ A } & \multicolumn{1}{l}{ B } \\
\hline Smith & 18.20 & -0.02374 & 0.20284 & \\
Oswin & 12.81 & 0.09791 & 0.82103 & \\
Halsey & 31.83 & 0.06612 & 1.01216 & \\
Flory-Huggins & 15.47 & 0.00901 & 4.54389 & \\
Kuhn & 3.54 & 0.12267 & 0.73149 & -0.06088 \\
GAB & 7.24 & 0.09327 & 0.94428 & 1.37330 \\
\hline
\end{tabular}

a. For GAB model, $A=M_{0}$ (monolayer moisture content), $B=k$ (constant correcting properties of multilayer molecules with respect to the bulk liquid); $C$, Guggenheim constant.

properties of the sorbate in the multilayer region through the introduction of a third parameter, $k$. This model showed a remarkable fit over a wide range of $a_{\mathrm{w}}$ values and a better evaluation of water tightly bound by the primary adsorption sites (Bizot, 1984). Also, the GAB model is simpler than the Kuhn model, since the GAB model does not include a logarithmic term. Therefore, although a slightly better fit was shown by the Kuhn equation, the GAB equation was used for estimating the film moisture contents $\left(M_{1}\right.$ and $\left.M_{2}\right)$ at various $\mathrm{RH}$ gradients.

The monolayer water content $\left(M_{0}\right)$ estimated from the GAB equation $(0.0933 \mathrm{~g} / \mathrm{g}$ dry matter) was slightly lower than that $(0.1052 \mathrm{~g} / \mathrm{g}$ dry matter) estimated by Gennadios and Weller (1994) for a similar WG film. The lower value was probably due to the higher protein content (minimum $80 \%$ on dry basis), and therefore lower starch content, of the WG product used in the present study than the WG product (75\% protein on dry basis) used by Gennadios and Weller (1994). Starch is more effective in depressing $a_{\mathrm{w}}$ than protein. The parameter $k$ (presented as $B$ in Table 5) in the GAB model is a constant correcting the properties of the multilayer molecules with respect to the bulk liquid.
The lower the $k$ value from unity, the lower the sorption of water. The $k$ value obtained in our study (0.9443) was greater than reported $k$ values ( 0.84) for proteins (Chirife et al., 1992). Most likely, the large amounts of hygroscopic glycerol incorporated into the films $(40 \%, \mathrm{w} / \mathrm{w}$, of WG) resulted in higher moisture sorption than that reported for proteins. Debeaufort et al. (1994) also observed increased monolayer water content with increased level of $a_{\mathrm{w}}$ depressants (plasticizers) in hydrophilic methylcellulose films.

\subsection{Effective solubility and diffusion coefficients}

For each studied RH gradient, $S_{\text {eff }}$ was calculated (Table 3) from Equation (7) after estimates for $M_{1}$ and $M_{2}$ were obtained from the fitted GAB model. Also, Equation (8) was used to calculate $D_{\text {eff }}$ values at each RH gradient (Table 3 ). As expected, $S_{\text {eff }}$ and $D_{\text {eff }}$ also increased, similar to $P_{\text {eff }}$ as the $\mathrm{RH}$ gradient applied across films moved upwards in the RH spectrum. Similar behavior has been documented for other hydrophilic films from calcium sodium pectinate (Schultz et al., 1949), hydroxypropyl methylcellulose/ethylcellulose (Woodruff et al., 1972), and hydroxypropyl methylcellulose/fatty acids (Kamper and Fennema, 1984).

\section{Conclusions}

$P_{\text {eff }}, S_{\text {eff }}$ and $D_{\text {eff }}$ values of cast hydrophilic WG film increased substantially as the $\mathrm{RH}$ gradient applied across the films increased in the RH spectrum. Sorbed water induced film plasticization, increased polymer chain mobility and, thus, facilitated water vapor diffusion through the film. It was shown that water vapor transport parameters of WG films (and likely of other hydrophilic protein-based films) at given $\mathrm{RH}$ gradient conditions cannot be predicted from available data obtained at different $\mathrm{RH}$ gradient conditions. Instead, testing of such films at the expected conditions of actual use in packaging applications is necessary to quantify the water vapor permeation through the films. 


\section{References}

Ali, Y., Ghorpade, V. M., and Hanna, M. A., 1997. Properties of thermally-treated wheat gluten films. Ind. Crops Prod. 6, pp. 177-184.

Ashley, R. J., 1985. Permeability and plastics packaging. In: Comyn, J., Editor, 1985. Polymer Permeability Elsevier Applied Science, London, pp. 269-308.

Aydt, T. P., Weller, C. L., and Testin, R.F., 1991. Mechanical and barrier properties of edible corn and wheat protein films. Trans. ASAE 34, pp. 207-211.

Bizot, H., 1984. Using the 'G.A.B.' model to construct sorption isotherms. In: Jowitt, R., Escher, F., Hallströrm, B., Meffert, H. F. T., Spiess, W. E. L., and Vos, G., Editors, 1984. Physical Properties of Foods, Elsevier Applied Science, London, pp. 27-41.

Boquet, R., Chirife, J., and Iglesias, H. A., 1978. Equations for fitting water sorption isotherms of foods: II. Evaluation of various two-parameter models. J. Food Technol. 13, pp. 319-327.

Briston, J. H., 1988. Plastics Films (3rd ed.), Wiley, New York, p. 434.

Chirife, J., Timmermann, E. O., Iglesias, H. A., and Boquet, R., 1992. Some features of the parameter $\mathrm{k}$ of the GAB equation as applied to sorption isotherms of selected food materials. J. Food Eng. 15, pp. 75-82.

Debeaufort, F., Voilley, A., and Meares, P., 1994. Water vapor permeability and diffusivity through methylcellulose edible films. J. Membr. Sci. 91, pp. 125-133.

Gencturk, M. B., Bakshi, A. S., Hong, Y. C., and Labuza, T. P., 1986. Moisture transfer properties of wild rice. J. Food Proc. Eng. 8, pp. 243-261.

Gennadios, A., and Weller, C.L., 1994. Moisture adsorption by grain protein films. Trans. ASAE 37, pp. 535-539.

Gennadios, A., Weller, C. L., and Testin, R. F., 1993. Modification of physical and barrier properties of edible wheat gluten-based films. Cereal Chem. 70, pp. 426-429.

Gennadios, A., McHugh, T. H., Weller, C. L., and Krochta, J. M., 1994. Edible coatings and films based on proteins. In: Krochta, J. M., Baldwin, E. A., and Nisperos-Carriedo, M., Editors, 1994. Edible Coatings and Films to Improve Food Quality, Technomic Publishing, Lancaster, PA, pp. 201-277.
Gennadios, A., Brandenburg, A. H., Park, J. W., Weller, C. L., and Testin, R. F., 1994. Water vapor permeability of wheat gluten and soy protein isolate films. Ind. Crops Prod. 2, pp. 189-195.

Gennadios, A., Weller, C. L., and Gooding, C. H., 1994. Measurement errors in water vapor permeability of highly permeable, hydrophilic edible films. J. Food Eng. 21, pp. 395-409.

Ghorpade, V. M., Li, H., Gennadios, A., and Hanna, M. A, 1995. Chemically modified soy protein films. Trans. ASAE 38, pp. 1805-1808.

Gontard, N., Guilbert, S., and Cuq, J. L., 1992. Edible wheat gluten films: Influence of the main process variables on film properties using response surface methodology. J. Food Sci. 57, pp. 190-195 also p. 199.

Gontard, N., Guilbert, S., and Cuq, J. L., 1993. Water and glycerol as plasticizers affect mechanical and water vapor barrier properties of an edible wheat gluten film. J. Food Sci. 58, pp. 206-211.

Gontard, N., Duchez, C., Cuq, J-L., and Guilbert, S., 1994. Edible composite films of wheat gluten and lipids: Water vapour permeability and other physical properties. Int. J. Food Sci. Technol. 29, pp. 39-50.

Herald, T. J., Gnanasambandam, R., McGuire, B. H., and Hachmeister, K. A., 1995. Degradable wheat gluten films: Preparation, properties and applications. J. Food Sci. 60, pp. 1147-1150 also p. 1156.

Kamper, S. L., and Fennema, O., 1984. Water vapor permeability of an edible, fatty acid, bilayer film. J. Food Sci. 49, pp. 1482-1485.

Kuhn, I., 1964. A new theoretical analysis of adsorption phenomena. Introductory part: The characteristic expression of the main regular types of adsorption isotherms by a singe simple equation. $J$. Colloid. Sci. 19, pp. 685-698.

McHugh, T. H., and Krochta, J. M., 1994. Permeability properties of edible films. In: Krochta, J. M., Baldwin, E.,A., and Nisperos-Carriedo, M., Editors, 1994. Edible Coatings and Films to Improve Food Quality, Technomic Publishing, Lancaster, PA, pp. 139-187.

McHugh, T. H., Avena-Bustillos, R., and Krochta, J. M., 1993. Hydrophilic edible films: Modified procedure for water vapor permeability and explanation of thickness effects. J. Food Sci. 58, pp. 899-903.

Myers, A. W., Meyer, J. A., Rogers, C. E., Stannett, V., and Szwarc, M., 1962. The permeation of water vapor. In: Kouris, M., Editor, 1962. Permeability of 
Plastic Films and Coated Paper to Gases and Vapors. TAPPI Monograph Series No. 23, Technical Association of the Pulp and Paper Industry, New York, pp. 63-77.

Oswin, C. R., 1946. Kinetics of package life. III. Isotherm. J. Chem. Ind. 65, pp. 419-421.

Park, H. J., and Chinnan, M. S., 1995. Gas and water barrier properties of edible films from protein and cellulosic materials. J. Food Eng. 25, pp. 497-507.

Rogers, C. E., 1985. Permeation of gases and vapours in polymers. In: Comyn, J., Editor, 1985. Polymer Permeability, Elsevier Applied Science, London, pp. 11-73.

SAS, 1993. SAS/STAT User's Guide. Release 6.08. SAS Institute, Cary, NC..

Schultz, T. H., Miers, J. C., Owens, H. S., and MacLay, W. D., 1949. Permeability of pectinate films to water vapor. J. Phys. Colloid Chem. 53, pp. 1320-1330.
Schwartzberg, H. G., 1986. Modeling gas and vapour transport through hydrophilic films. In: Mathlouthi, M., Editor, 1986. Food Packaging and Preservation, Elsevier, New York, pp. 115-135.

Smith, S. E., 1947. The sorption of water vapor by high polymers. J. Am. Chem. Soc. 69, pp. 646-651.

Wolf, W., Spiess, W. E. L., Jung, G., Weisser, H., Bizot, H., and Duckworth, R. B., 1984. The water-vapour sorption isotherms of microcrystalline cellulose (MCC) and of purified potato starch: results of a collaborative study. J. Food Eng. 3, pp. 51-73.

Woodruff, C. W., Peck, G. E., and Banker, G. S., 1972. Effect of environmental conditions and polymer ratio on water vapor transmission through free plasticized cellulose films. J. Pharm. Sci. 61, pp. 1956-1959. 